\title{
ARTICLES
}

\section{The Feasibility of Constructing Profiles of Native Americans from the People of Color Racial Identity Attitude Scale: A Brief Report}

\author{
Alfred Bryant, Jr. and Stanley B. Baker \\ One hundred and fifty Lumbee Native American college students participated in an inves- \\ tigation of the feasibility of constructing profiles of Native Americans from the People of \\ Color Racial Identity Attitude Scale (PRIAS; Helms, 1995b). Findings suggest that Helms's \\ instrument may be feasible for constructing racial identity attitudes of Native Americans.
}

ndividuals identify themselves by various distinguishable racial, ethnic, and cultural group characteristics (Locke, 1998). According to Arroyo (1995), the awareness of clearly distinguished boundaries between members of differing groups defines group identification. Distinguishable racial, ethnic, and cultural group boundaries are skin color, country of origin, language, and religion (Canabal, 1995). The formation of these boundaries is important to the psychological adjustment and development of individuals (Alvarez, 1996).

A newly articulated identity is now being sought that further defines these boundaries and helps to refine one's place in this increasingly complex society. This new identity is being articulated in the conceptualization of racial identity development. Racial identity involves the realization that one shares a collective racial culture with a particular racial

[AU1] group (Helms, 1990a). Racial identity development focuses on the process that racially or culturally diverse groups of people go through in developing a healthy, well-adjusted racial or cultural identity (Atkinson, Morten, \& Sue, 1998; Cross, 1995; Helms, 1994).

According to Cross, Parham, and Helms (1991), the more efficiently individuals are able to resolve conflicts between the old and new worldview, the higher they are able to progress within racial identity models. Thus, individuals who are never able to find resolution in regards to these matters tend to remain at lower stages of racial identity

[AU2] development. On the other hand, individuals who embrace and work to expand their own self-awareness and acceptance of others are more able to move freely to higher stages of racial identity development.

Racial identity development theory is condensed into models that map out the process of racial identity development. The models contain stages that represent an individual's psy-

Alfred Bryant, Jr., School of Education, University of North Carolina at Pembroke. Stanley B. Baker, Counselor Education program, North Carolina State University. The authors wish to thank Janet Helms, Don C. Locke, Patricia Horan, Herbert A. Exum, and Joy M. Smith for their assistance in the research reported in this study. Correspondence concerning this article should be addressed to Alfred Bryant, Jr., School of Education, P.O. Box 1510, University of North Carolina at Pembroke, Pembroke, NC 28372 (e-

[AU1a] mail: alfred.bryant@uncp.edu). 
chological progress from lower to higher stages of development. Typically, lower stages represent less-defined, underdeveloped psychological mentalities (Helms 1995a).

Helms suggests using the People of Color Racial Identity Scale (PRIAS; Helms, 1995b) as a method of constructing profiles for individuals, but she does not use it to classify people according to distinct categories. To this end, Helms discontinued the concept of stage and now uses the word status to conceptualize identity (Helms \& Cook, 1999). She approaches racial identity from an expanded cognitive perspective and suggests that each status profile be seen as a distinctive worldview. Worldview can influence one's patterns of thought, behavior, decision making, as well as how one defines particular events in one's life (Cross et al., 1991).

Stage models began to appear in the late 1960s apparently as a result of civil rights activities (Cross \& Vandiver, 2001). Cross's (1995) Black Racial Identity Development Theory is based on the Black experience with oppression encountered during this time period. This theory presents the racial identity transition of African Americans from a proWhite and anti-Black attitude to a pro-Black orientation. The Atkinson and colleagues (1998) Minority Identity Development Theory (which is based on Cross's work) was created in response to the experiences African Americans, Native Americans, Hispanics, Asian Americans, and other ethnic groups have had with historical oppression by White Americans. The effects of this past oppression and present attitudes of racism exhibited by many White Americans have influenced the development of these theories.

According to Helms (personal communication, May 1, 1997), Native Americans have an underlying racial identity with commonalities that transcend different tribal populations. Although there are tribal differences, characteristics exist that cause Native Americans to share a common racial identity. The differences are evident. "Race is how people or society responds to you because of how you look (e.g., racism); culture is what a group of selfdefined people does to define itself and survive (i.e., customs, traditions, and rituals). In this country, Native Americans (like everyone else) have both. Therefore, both adaptations to racism (racial identity) and different cultural socialization (acculturation) should be factors in their psychological development" (Helms, personal communication, May 1, 1997).

In addition, there are those who believe that minority groups share similar experiences of being oppressed by the dominant culture (Atkinson et al., 1998; Sue, 2001). According to Helms (1994), Native Americans have experienced the longest battle with historic oppression by White people. These experiences with oppression have helped form the racial identity of this group of people. Although little research has been done with Native American adolescents in general (Bee-Gates, Howard-Pitney, LaFromboise, \& Rowe, 1996), even less attention has been directed toward their racial or ethnic identity (Martinez \& Dukes, 1997; Mihesuah, 1999). Only a few published descriptions of Native American ethnic identity instruments have been found, and those found generally were only used once (Fischer \& Moradi, 2001).

In the United States, people of color have developed an internalized racism resulting from the visible and blatant societal stereotypes placed on them (Helms, 1995a). Recognizing and overcoming the psychological manifestations of internalized racism is the central theme in the racial identity development of people of color (Helms, 1995a). Helms's theory, which explains this process, integrates aspects of Cross's (1995) Negro-to-Black conversion model, Atkinson and colleagues' (1998) model, Erikson's (1963) collective identity model, and Kohut's (1971) self psychology (Helms \& Cook, 1999). Recognition of the problem takes place in a sequential and deliberate fashion.

Conformity, the first status in Helms's People of Color Racial Identity model, represents a devaluing of one's own racial group and a desire to embrace White culture. Dissonance, the second status, represents a state of confusion concerning one's racial identity. The third status, Immersion-Emersion, delineates an embracing of one's own culture and a refusal of White culture. "Note that Immersion and Emersion are described as a single 
status. I think that eventually it will be possible to distinguish them empirically as well as theoretically, although this is not the case at present" (Helms, 1995a, p. 190). Status four, Internalization, depicts a positive racial identity with clearly defined racial attributes. The final status, Integrative Awareness, illustrates an ability to value one's own culture and at the same time empathize and seek to understand the culture of others. This status has not been operationalized and therefore does not appear as a part of the research instrument.

Helms's (1995b) scale, which operationalizes her theory, has been modified and renamed several times since its inception. The People of Color Racial Identity Attitude Scale (PRIAS; Helms, 1995b) measures the racial identity attitudes derived from perceived shared experiences with racial oppression of those residents of the United States whose ancestry appears to be Asian, African, Latino or Latina, or Native American.

Helms's (1995b) People of Color Racial Identity Scale may be a useful tool constructing profiles of the racial identity development of Native Americans. The present study provided an opportunity for accumulating empirical data and suggesting future research directions. The research questions for the present study were (a) What is the factor structure of the PRIAS for a sample of Lumbee Native Americans? and (b) What is the reliability estimate of the PRIAS for the scores of a sample of Lumbee Native Americans?

\section{METHOD}

\section{Participants}

A sample of 150 Lumbee Native Americans (68 males, 82 females ) was recruited from two higher education institutions. Of the $150,37 \%(n=55)$ attended a southeastern land grant university and $63 \%(n=95)$ attended a small southeastern public university. All participants were single and were from Robeson County, North Carolina. The two samples were compared on PRIAS subscales (i.e., conformity, dissonance, immersion, and internalization scales), and no significant differences emerged. The $t$ test summaries for the scales respectively were $t(148)=-1.19, p=.24, \mathrm{~d}=.29 ; t(148)=-.97, p=.34, \mathrm{~d}=.22$; $t(148)=-.68, p=.50, \mathrm{~d}=.14 ; t(148)=1.75, p=.08, \mathrm{~d}=.28$. Sixty-three participants $(42 \%)$ were freshmen, $24(16.67 \%)$ sophomores, 28 (18.67\%) juniors, and $35(23 \%)$ seniors. The mean age was $19.61(S D=1.7)$.

\section{Instrumentation}

The People of Color Racial Identity Attitude Scale (PRIAS; Helms, 1995b) contains 50 questions that are divided into four subscales corresponding to four of the five statuses of Helms's PRIAS. Participants are asked to respond to each item of the PRIAS using a Likert scale $(1=$ strongly agree to $5=$ strongly disagree $)$. Higher scores on each of the four subscales indicate stronger levels of the relevant racial identity attitudes. The subscale scores range from 10 to 50 on the Conformity-Preencounter subscale, 15 to 75 on the Dissonance subscale, 13 to 65 on the Immersion-Resistance subscale, and 10 to 50 on the Internalization subscale. Alvarez (1996), Helms and Carter (1990), Kohatsu (1992), and Miville (1996) reported alpha reliability coefficients for the scores on subscales ranging from a high of .87 to a low of .61 .

\section{Procedure}

Based on Gorsuch's (1997) guidelines for factor analytic investigations, a sample of 150 prospective participants was recruited to achieve sufficient statistical power. Each participant received a packet containing a cover letter, an informed consent statement, a demographic data sheet, and the People of Color Racial Identity Attitude Scale. The first author 
collected the data when the participants had finished and proceeded to convert the data for analysis. All 150 prospective participants invited to take part agreed to do so. Participation was voluntary and anonymous, and no inducement was offered for participating in the study.

\section{Data Analysis}

An exploratory factor analysis was performed on the PRIAS item responses to obtain evidence of construct validity, and a Cronbach (1951) alpha internal consistency coefficient was used to obtain evidence of reliability.

\section{RESULTS}

\section{Exploratory Factor Analysis}

Table 1 shows the rotated structure coefficient for each item from the exploratory factor analysis. Eigenvalues greater than 1.00 identified the presence of 16 factors. A scree test indicated four factors. Twenty-nine of Helms's (1995b) original 50 items had structure coefficients above .50 . Helms's proposed four factors were identified with the following structure coefficients in this study: Factor I had 12 items (11 from Helms's ImmersionResistance status); Factor II had 6 items (5 from Helms's Internalization status); Factor III had 5 items (all from Helms's Conformity-Preencounter status); and Factor IV had 6 items (all from Helms's Dissonance status). Immersion-Resistance accounted for 7\% of the total variance with Internalization accounting for $4 \%$, Conformity-Preencounter accounting for $4 \%$, and Dissonance accounting for $4 \%$. The four factor solution accounted for $19 \%$ of the total variance.

\section{Reliability Estimate}

Scale reliability for the scores of the present sample was assessed by calculating coefficient alphas for the four subscales. Subscale reliability estimates in the present sample were $.61, .69, .83$, and .73 for the Conformity-Preencounter, Dissonance, ImmersionResistance, and Internalization subscales, respectively. Interscale correlations for the four subscales range from -.11 to .51 .

\section{DISCUSSION}

The findings suggest that Helms's (1995b) People of Color Racial Identity Attitude Scale may be useful for constructing profiles of racial identity attitudes of Native Americans. Further research with Native American participants is encouraged. Possible investigations are replications of the present validity study with participants from other Native American tribes and other age cohorts and relationships between Native American racial identity development and postsecondary education choices, academic performance, retention rates, graduation rates, and career choice. Information from the PRIAS may help counseling practitioners understand the cultural context of Native American clients and how racial identity attitudes affect other parts of their lives.

Enormous variability exists within Native American Indian populations (Fischer \& Moradi, 2001). "Locke asserts that the differences existing between members of the dominant culture and members of ethnically diverse cultures are real" (Fuertes \& Gretchen, 2001). Racial identity attitude development of Native Americans seems to be very complex due to vast tribal differences. According to Alexander and Suzuki (2001), within-group differences in racial and ethnic groups exceed between-group differences on most assessed psychological constructs. Studies investigating the racial identity attitude development process may 


\section{TABLE 1}

Rotated Structure Coefficients for the People of Color Racial Identity Scale

\begin{tabular}{|c|c|c|c|c|c|}
\hline Item & Factor 1 & Factor 2 & Factor 3 & Factor 4 & $h^{2}$ \\
\hline \multicolumn{6}{|l|}{ Preencounter } \\
\hline Anglos are superior & .08 & -.14 & .56 & .02 & .35 \\
\hline \multicolumn{6}{|l|}{ More comfortable with Anglos } \\
\hline than my own & -.38 & .07 & .09 & .40 & .32 \\
\hline \multicolumn{6}{|l|}{ My people have not added much } \\
\hline to society & .04 & -.28 & -.01 & .29 & .16 \\
\hline Embarassed of own race & -.10 & .00 & .56 & .33 & .43 \\
\hline I would succeed if I was White & .07 & .09 & .56 & .20 & .37 \\
\hline Anglos are more attractive & -.14 & -.04 & .53 & .18 & .34 \\
\hline Indians should act like Anglos & -.14 & -.02 & .68 & .09 & .48 \\
\hline Limit self to Anglo activities & .30 & -.09 & .45 & .13 & .31 \\
\hline Minorities blame Anglos too much & -.16 & .37 & .21 & .23 & .26 \\
\hline \multicolumn{6}{|l|}{ I am sometimes embarrassed by } \\
\hline my people & .26 & .15 & .10 & .36 & .23 \\
\hline \multicolumn{6}{|l|}{ Dissonance } \\
\hline \multicolumn{6}{|l|}{ Minorities should stop blaming } \\
\hline Anglos & -.18 & .60 & -.02 & .07 & .40 \\
\hline Why do Anglos mistreat minorities & .44 & .33 & .14 & .11 & .33 \\
\hline Feel embarrassed of my people & -.03 & -.07 & .07 & .57 & .34 \\
\hline Don't know where I belong & -.04 & -.17 & .29 & .59 & .46 \\
\hline Question beliefs & .12 & -.07 & .11 & .69 & .51 \\
\hline I can learn much from my race & .22 & .41 & -.02 & .30 & .31 \\
\hline \multicolumn{6}{|l|}{ Can learn to be human from own } \\
\hline race & .19 & .20 & .34 & .22 & .24 \\
\hline Unsure if race is an asset or deficit & -.06 & -.11 & .30 & .54 & .39 \\
\hline Sometimes think Angos are superior & .20 & .00 & .42 & .15 & .24 \\
\hline Proud and ashamed of race & -.09 & .06 & .31 & .51 & .37 \\
\hline Think a lot about values and beliefs & .38 & .20 & -.03 & .17 & .21 \\
\hline Unsure of feelings of self & .13 & -.03 & .13 & .59 & .39 \\
\hline Anglos are difficult to understand & .70 & -.17 & .34 & .07 & .64 \\
\hline \multicolumn{6}{|l|}{ Replace old friends with same } \\
\hline race friends & .47 & .06 & .12 & .05 & .24 \\
\hline \multicolumn{6}{|l|}{ Anxious about feelings of own } \\
\hline people & .18 & .31 & .11 & .25 & .20 \\
\hline Value Anglo culture & -.25 & .00 & .23 & .49 & .36 \\
\hline \multicolumn{6}{|l|}{ Immersion } \\
\hline More involved in own culture & .66 & -.11 & -.01 & -.19 & .49 \\
\hline Angry at Anglos' historic treatment & & & & & \\
\hline of minorities & .64 & -.02 & .33 & -.12 & .53 \\
\hline \multicolumn{6}{|l|}{ Want to know more about my } \\
\hline culture & .33 & .37 & -.15 & .00 & .27 \\
\hline Limit self to own race activities & .23 & -.18 & .01 & .24 & .14 \\
\hline Can't trust most Anglos & .67 & -.34 & .26 & .05 & .64 \\
\hline \multicolumn{6}{|l|}{ Society would be better if it were } \\
\hline based on my culture & .50 & -.06 & -.10 & .08 & .27 \\
\hline Determined to find cultural identity & .47 & .43 & -.11 & .02 & .42 \\
\hline Most Anglos aren't sensitive & .64 & -.24 & .33 & -.03 & .58 \\
\hline Reject Anglo culture & .61 & -.18 & -.09 & .17 & .44 \\
\hline \multicolumn{6}{|l|}{ Fighting oppression is very } \\
\hline important & .52 & .06 & -.21 & .07 & .32 \\
\hline Prefer being with own race & .67 & .12 & .05 & -.08 & .48 \\
\hline Angry at Anglo treatment of Indians & .59 & .31 & .17 & .10 & .49 \\
\hline Follow own cultural teachings & .56 & -.04 & -.18 & -.05 & .35 \\
\hline Dislike people acting Anglo & .65 & -.01 & -.04 & .25 & .48 \\
\hline \multicolumn{6}{|l|}{ Internalization } \\
\hline My culture has given me many & & & & & \\
\hline strengths & .34 & .29 & -.37 & $\begin{array}{c}.21 \\
\text { (Continued }\end{array}$ & $\begin{array}{l}.38 \\
x t \text { page) }\end{array}$ \\
\hline
\end{tabular}


TABLE 1 (Continued)

Rotated Structure Coefficients for the People of Color Racial Identity Scale

\begin{tabular}{lccrrr}
\hline \hline Item & Factor $\mathbf{1}$ & Factor $\mathbf{2}$ & Factor $\mathbf{3}$ & Factor $\mathbf{4}$ & $\boldsymbol{h}^{\mathbf{2}}$ \\
\hline Internalization (continued) & & & & & \\
Am comfortable wherever I am & -.21 & .34 & -.44 & -.08 & .36 \\
All races have pluses and minuses & -.22 & .41 & .20 & .48 & .49 \\
No cultures are superior & -.09 & .39 & -.34 & -.03 & .28 \\
Pride in culture & .30 & .58 & -.23 & -.14 & .50 \\
Cultures can learn from each other & -.15 & .73 & .01 & -.07 & .57 \\
Enjoy Anglo culture & -.33 & .36 & .28 & -.06 & .33 \\
Enjoy all races & -.14 & .67 & -.18 & -.06 & .50 \\
Good and bad in all & .13 & .59 & -.06 & -.24 & .42 \\
Minorities should not blame Anglos & -.18 & .60 & -.02 & .07 & .40 \\
Am comfortable with my race & .17 & .34 & -.34 & .14 & .28 \\
& & & & & \\
Eigenvalue & 6.87 & 6.16 & 3.66 & 2.15 & \\
Percentage of variance & 6.74 & 4.30 & 3.96 & 3.83 & \\
\hline
\end{tabular}

Note. $h^{2}=$ communality.

lead to new ways of looking at and understanding these differences. Further exploration of racial identity attitude development may very well provide information that will help counseling practitioners, educators, and other helping professionals to understand Native Americans better.

Generalizing from the present study is limited to one Native American cohort and to freshman and sophomore college students. On the other hand, the findings provide new information about Helms's (1995b) scale, and the range of people of color whose responses have been investigated has been increased. Helms's effort to develop a psychometrically sound measure of racial identity development seems to have received some support. Although there is still much to do in this domain, the quest seems promising.

\section{REFERENCES}

Alexander, C. M., \& Suzuki, L. A. (2001). Measurement of multicultural constructs: Integration and research directions. In J. G. Ponterotto, J. M. Casas, L. A. Suzuki, \& C. M. Alexander (Eds.), Handbook of multicultural counseling (2nd ed., pp. 499-506).Thousand Oaks, CA: Sage.

Alvarez, A. (1996). Asian American racial identity: An examination of world views and racial adjustment (Doctoral dissertation, University of Maryland, College Park, 1996). Dissertation Abstracts International, 57, Z6554.

Arroyo, C. G. (1995). Racial identity, academic achievement, and the psychological well-being of economically disadvantaged adolescents. Journal of Personality and Social Psychology, 69, 903-914.

Atkinson, D. R., Morten, G., \& Sue, D. W. (1998). Counseling American minorities (5th ed.). Boston: McGraw-Hill.

Bee-Gates, D., Howard-Pitney, B., LaFromboise, T., \& Rowe, W. (1996). Help-seeking behavior of Native American Indian high school students. Professional Psychology: Research and Practice, 27(5), 495-499.

Canabal, I. (1995). Latino group identities, collective and personal self-esteem (Doctoral dissertation, University of Maryland, College Park, 1995). Dissertation Abstracts International, 56, Z4574.

Cronbach, L. J. (1951). Coefficient alpha and the internal structure of tests. Psychometrica, 16, 297-334.

Cross, W. E., Jr. (1995). The psychology of nigrescence: Revising the Cross model. In J. G. Ponterotto, J. M. Casas, L. A. Suzuki, \& C. M. Alexander (Eds.), Handbook of multicultural counseling (pp. 93122). Thousand Oaks, CA: Sage.

Cross, W. E., Parham, T. A., \& Helms, J. E. (1991). The stages of Black identity development: Nigrescence models. In R. L. Jones (Ed.), Black psychology (3rd ed., pp. 319-338). Berkeley, CA: Cobb and Henry Publishers. 
Cross, W. E., \& Vandiver, B. J. (2001). Nigrescence theory and measurement. In J. G. Ponterotto, J. M. Casas, L. A. Suzuki, \& C. M. Alexander (Eds.), Handbook of multicultural counseling (2nd ed., pp. 371-393). Thousand Oaks, CA: Sage.

Erikson, E. (1963). Childhood and society (2nd ed.). New York: Norton.

Fischer, A. R., \& Moradi, B. (2001). Racial and ethnic identity: Recent developments and needed directions. In J. G. Ponterotto, J. M. Casas, L. A. Suzuki, \& C. M. Alexander (Eds.), Handbook of multicultural counseling (2nd ed., pp. 341-370). Thousand Oaks, CA: Sage.

Fuertes, J. N., \& Gretchen, D. (2001). Emerging theories of multicultural counseling. In J. G. Ponterotto, J. M. Casas, L. A. Suzuki, \& C. M. Alexander (Eds.), Handbook of multicultural counseling (2nd ed., pp. 509-541). Thousand Oaks, CA: Sage.

Gorsuch, R. L. (1997). Exploratory factor analysis: Its role in item analysis. Journal of Personality Assessment, 68, 532-560.

Helms, J. E. (1994). The conceptualization of racial identity and other "racial" constructs. In E. J. Trickett, R. J. Watts, \& D. Birman (Eds.), Human diversity (pp. 285-311). San Francisco: Jossey-Bass.

Helms, J. E. (1995a). An update of Helms's White and people of color racial identity models. In J. G. Ponterotto, J. M. Casas, L. A. Suzuki, \& C. M. Alexander (Eds.), Handbook of multicultural counseling (pp. 181-198). Thousand Oaks, CA: Sage.

Helms, J. E. (1995b). The People of Color (POC) Racial Identity Attitude Scale. Unpublished manuscript, University of Maryland, College Park.

Helms, J. E., \& Carter, R. T. (1990). Development of the White Racial Identity Inventory. In J. E. Helms (Ed.), Black and White racial identity: Theory, research, and practice (pp. 67-80). Westport, CT: Greenwood Press.

Helms, J. E., \& Cook, D. A. (1999). Using race and culture in counseling and psychotherapy: Theory and process. Boston: Allyn and Bacon.

Kohatsu, E. L. (1992). The effects of racial identity and acculturation on anxiety, assertiveness, and ascribed identity among Asian American college students (Doctoral dissertation, University of Maryland, College Park, 1992). Dissertation Abstracts International, 54, Z1102.

Kohut, H. (1971). The analysis of the self: A systematic approach to the psychoanalytic treatment of narcissistic personality disorders. New York: International Universities Press.

Locke, D. C. (1998). Increasing multicultural understanding (2nd ed). Newbury Park, CA: Sage.

Martinez, R. O., \& Dukes, R. L. (1997). The effects of ethnic identity, ethnicity, and gender on adolescent well-being. Journal of Youth and Adolescence, 26, 503-516.

Mihesuah, D. (1999). American Indian identities: Issues of individual choice and development. In D. Champaign (Ed.), Contemporary Native American cultural issues (pp. 13-37). Walnut Creek, CA: Alta Mira Press.

Miville, M. L. (1996). Exploring relationships of cultural, gender, and personal identity among Latinos and Latinas (Doctoral dissertation, University of Maryland, College Park, 1996). Dissertation Abstracts International, 58, Z458.

Sue, D. W. (2001). Surviving monoculturalism and racism: A personal and professional journey. In J. G. Ponterotto, J. M. Casas, L. A. Suzuki, \& C. M. Alexander (Eds.), Handbook of multicultural counseling (2nd ed., pp. 45-54). Thousand Oaks, CA: Sage.

\section{Author Query List BRYANT}

Author: Your article has been edited for grammar, consistency, and to conform to ACA and APA journal style. To expedite publication, we generally do not query every routine grammatical or style change made to the manuscript, although substantive changes have been noted. Note, the issue is not finalized, so page numbers of your article may change. Pay careful attention to your tables (if any) and proof carefully as information has been re-keyed and edited for APA tabular style. Please review article carefully and provide answers to the following specific queries:

[AU1a: Please confirm all information is accurate.]

[AU1: This reference is not listed in the reference list. Do you mean Helms, 1995a?]

[AU2: Embrace what? Please clarify]

[AU3: Change OK? Reorganized paragraph to give it a better opening sentence.]

[AU4: Added the word "helped"- unless you mean that oppression is the only experience that forms racial identity?]

[AU5: En dash per APA Style: OK instead of slash?]

[AU6: Many of the changes in the following paragraph were made by the field editor.]

[AU7: Elsewhere this is spelled "Preencounter," which I assume is the correct spelling.] 
Measurement and Evaluation in Counseling and Development * April $2003 \quad * \quad$ Volume 36 